\title{
An Empirical Research On The Antecedent-Consequence Integrating Model Of Recreationist-Environment Fit: A Case Study On Sport Tourists In Guaninting Waters Of Penghu
}

\author{
Cheng-Lung Wu, National Penghu University of Science and Technology, Taiwan
}

\begin{abstract}
The purpose of this research is to verify the validity of an antecedent-consequence integrating model of recreationist-environment fit ( $R-E$ fit). This study selected the marine sport tourists in the Guaninting waters of Penghu as the subjects. The research used a questionnaire survey with 300 questionnaires handed out and returned. Of these, 253 were valid and 47 were invalid; therefore, the effective response rate was $84.3 \%$. Then the associated data were collected for descriptive statistical analysis and structural equation modeling analysis using statistical software SPSS20.0 and Smart PLS 2.0. The research results reveal the following conclusions: (1) Familiarity has significant influence on $R$-E fit; (2) Self-efficacy has significant influence on $R$-E fit; (3) Restorative environment features have significant influence on $R$-E fit; (4) Recreational environment hassles have little significant influence on $R$-E fit; (5) $R$-E fit has significant influence on flow experience; (6) $R$-E fit has significant influence on recreational satisfaction; and (7) $R$-E fit has significant influence on destination loyalty. Accordingly, at the end of this study, suggestions are offered for future research, along with implications for tourism management.
\end{abstract}

Keywords: Familiarity; Recreation Hassles; Flow Experience; Recreational Satisfaction; Destination Loyalty

\section{INTRODUCTION}

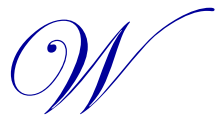
ith the trend of globalization, various sports from different places around the world have been presented to Taiwanese people through the media; this has diversified local recreations, such as various marine sports, which have elicited greater attention in recent years because of Taiwan's profuse marine recreational resources and the promotion of marine policies by the authorities concerned. Hence, a new form of tourism, marine sport tourism, has taken shape through the combination of tourism and sports, not only offering people the opportunity to participate in marine sports but also uplifting its attraction via the blending of sightseeing festivities and sports events. However, every tourism pattern still has its own issues that are worth investigating. Hsu (2005) indicates that the damage to the coastal landscape by public construction and private development projects is an on-going problem to marine sport tourism, which reduces potential development. Since the recreational environment is the most important space for people to enjoy marine sport tourism, discovering how to obtain a wonderful experience in such space has become a major concern of the participants.

Most of the related studies use recreation impact theory to probe the influence of the environment on the participants of recreation. Some studies adopt the notion of recreation impact (e.g., Chang, Lin, Chen \& Chan, 2010; Cheng, Lin, \& Tsai, 2011). However, others on recreational environment follow the concept of place attachment, which comprises two dimensions: place dependence and place identity. Place dependence is defined as people's assessment of a certain place, whose specialty and unique facilities or other functions are capable of satisfying 
personal demands and goals; place identity is described as people's connection to an environment, and their assimilation and adaptation to it (Williams, Patterson \& Roggenbuck, 1992). This dimension about the link between recreation and environment also echoes the viewpoint of place attachment presented by Bricker and Kerstetter (2000), i.e. a sense of belonging is the bond to a place, as felt by the users. Accordingly, whether personal recreational experience is compatible with the environment and the relation between recreationists and environmental attributes are both worth further investigation.

The concept of "fit" has been long applied to the management field (Valentine, Godkin \& Lucero, 2002; Vogel \& Feldman, 2009). It judges whether an individual can fit in with an organization, by investigating if one party can meet the demands of the other, or if both sides have the same values and faith. Muchinsky and Monahan (1987) indicate two different organization fits: supplementary fit and complementary fit. The former can be achieved when similar traits, such as the most-studied consistency of values and goals, are shared by an individual and other people in the environment. The latter occurs when the traits of individuals can compensate for the insufficient aspects of the environment. In 1991, Edwards exhibited a different viewpoint, indicating that person-job fit (P-J fit) was about the compatibility between a person and his/her job, i.e. how well the skill/capability of an individual could meet the specific conditions demanded by his/her job. The associated researches also reveal that increasing P-J fit can improve the job satisfaction of employees and significantly benefit the development of organizations (Cable, \& DeRue, 2002; Lauver \& Kristof-Brown, 2001).

In addition, some studies (Kristof-Brown, Zimmerman \& Johnson, 2005) which probed the fit between persons and environments, indicate that person-environment fit is broadly defined as the consistency between personal traits and environmental features. However, no matter which definition we prefer, these terminologies represent the intention to seek a symbiotic relationship between individuals and organizations, and their devotion to pursue a better environment. It is therefore worth investigating if we can apply the notion of person-organization fit mentioned above to the interaction between people and their environment. Tsaur and Lin (2012) describe the recreationists-environment fit (R-E fit) as the interaction between the recreationists and their environment. Tsaur, Liang and Lin (2012) were the first to apply the notion of "fit" to the recreational field, and performed an associated empirical study based on the mountain climbing activity. In other words, it is feasible to apply the concept of organizational fit to the recreational field. In recent years, the number of studies focusing on issues related to marine recreational environments (Onofri \& Nunes, 2013; Ramdas \& Mohamed, 2014) has been growing, and domestic marine sport tourism is increasingly popular. This study intends to verify if the antecedent-consequence integrating model established by Tsaur, Liang, and Lin (2012) can be applied to the recreationist-environment fit through a case study on the marine sport tourists in the Guaninting waters of Penghu, and provides associated suggestions for future research.

\section{LITERATURE REVIEW}

\section{Implication Of Recreationist-Environment Fit}

The notion of "fit" has been broadly applied to the management of organizations, and used to describe the compatibility between persons and environments. Tsaur et al. (2012) applied this notion to the recreational field and, based on the attention restoration theory and affordance theory, researched the notion of "fit" suitable for the recreational environment. They emphasize three types of fit: (1) Supplementary fit is the compatibility achieved when the recreationists and the administrations share similar values; (2) Demand-Ability fit is reached when the demands of the environment match the ability of recreationists; and (3) Need-Supply fit is obtained when the environment can satisfy the needs of recreationists. In terms of the marine sport tourism illustrated in this article, supplementary fit refers to a situation in which marine sport tourists and the administration both share common ideas, such as sustainable management of the environment, or similar cognition regarding how to manage recreationists.

Demand-ability fit (D-A fit) focuses on determining if the marine sport tourists have the required associated skills and knowledge, such as drowning prevention and first aid treatment. The D-A fit is high when the tourists possess such knowledge and skills. Need-supply fit (N-S fit) is used to describe whether the waters open for marine sport tourism can offer enough space and various sports to meet the different needs of the tourists. The above three 
R-E fits represent the level of interaction between the environment and the emotion of recreationists. The level of RE fit varies according to the participants' ability, needs and motivation.

\section{Factors Influencing Recreationist-Environment Fit}

Since there are numerous influencing factors, the relation between recreationists and the environment is always complicated. Huan, Shen, Weng and Tai (2002) believe that during the process of need-action-experience, the recreational needs and motivation of tourists are influenced by personal characteristics and past experience; each individual has different expectations, leading to various recreational activities, generating different experiences affected by environment features, types of activity and actual situations, and consequently obtaining different levels of satisfaction. Tsaur and Lin (2012) organized Table 1 listing the influencing factors of recreationist-environment fit. It links "personal antecedents" with familiarity and self-efficacy, "environmental antecedents" with restorative environmental features and environmental hassles, and "recreational outcome" with flow experience, satisfaction and destination loyalty.

Table 1. Influencing Factors of Recreationist-Environment Fit

\begin{tabular}{lll}
\hline Personal Antecedents & Environmental Antecedents & Recreation Outcome \\
\hline 1. Familiarity & 1. Restorative environment features & 1. Flow experience \\
2. Self-efficacy & 2. Environmental hassles & 2. Satisfaction \\
& & 3. Destination loyalty \\
\hline
\end{tabular}

Data source: Tsaur and Lin (2012)

After surveying related literature, the influencing factors of recreationist-environment fit are organized and described as follows:

\section{Familiarity}

Familiarity results from personal visiting experience and is related to the inclination toward the destination (Prentice, \& Andersen, 2000). When participants visit a venue, for example, if the environment can meet their demands, they will keep visiting that place, resulting in familiarity with it. Chen (2008) further indicates that familiarity is more than an influencing factor of travel choice. When travelers have higher subjective familiarity, environmental perception and emotional familiarity about the destination, their revisiting willingness in regard to that place will become more significant. In other words, it is concluded that when the marine sport tourists are more familiar with the environmental features or the waters where their activities are held, it is more likely they can fit in with the environment, and experience pleasure and satisfaction.

\section{Self-Efficacy}

Self-efficacy is formed by an individual through his/her judgment regarding his/her competence to complete a certain task (Bandura, 1977). Bandura also indicates that self-efficacy varies according to four aspects: performance accomplishment, vicarious experience, verbal persuasion and emotional arousal. Take someone who is very interested in swimming as an example: the improvement in swimming skill can be seen as performance accomplishment; the associated reports and videos are the vicarious experience; the support from family and friends can form verbal persuasion; and the relaxation obtained in the swimming process can be regarded as some kind of emotional arousal. In addition to the rise of self-efficacy, these factors can also make the participants of sea swimming feel that they are part of the marine sport tourism, generating the "fit" between persons and environments.

\section{Restorative Environment Features}

As early as 1982, Bammel and Burrus-Bammel posited that participating in recreational activity could generate six benefits to an individual: physiological, social, relaxation, educational, psychological and aesthetic. These benefits of participation can be obtained from either outdoor or indoor recreational activities. Tseng (2004) states four elements of restorative space: being away, extent, fascination and compatibility. When an environment offers these four elements and they are strong enough, it can create a progressive restoration experience. Take the surfer as an example; leaving the nine-to-five office routine requires being away; the on-going attraction of the 
surfers to the unique glamour of the sea and tropical atmosphere can be regarded as the extent; the smell of ocean and relaxing aura are the so-called fascination; and the perfect wave and impeccable surfing facilities are the compatibility of the environment. That is, when everything necessary comes together, the marine sport tourists can smoothly finish their activities and obtain what they expected; consequently, a high level of fit with the environment can be achieved.

\section{Hassles Of Recreational Environments}

The issues related to the impact of outdoor recreation have caused concern since the 1980s because of the growing number of outdoor activity participants who have been inflicting different levels of damage and creating hassles in the recreational environment. Schuster, Hammitt and Moore (2006) believe that in the 21st century, recreational conflicts can be regarded as recreational hassles, such as crowded space, discordant landscape, significant deviation from expectation, filthy environment and unpleasant noise.

Booth, Cessford, McCool and Espiner (2011) indicate that change of cognition, emotions and behavior can serve as an adaptation mechanism in coping with recreational environment hassles. Folkman, Lazarus, DunkelSchetter and Gruen (1986) deem that adaptation is the effort paid by the recreationists, a modification of cognition and behavior in order to meet the specific demands of the individual and environment. Folkman and Lazarus (1984) established an adaptation model, and their theory includes five elements: cognitive appraisal, adaptation of behavior, relation between persons and environments, short-term and long-term outcome, and stress. Potential stress appears in the interaction process between persons and environments; personal motivation to adopt an adjusting process is generated when one feels the potential stress through cognitive appraisal. Folkman et al. (1984) emphasize the relation between persons and environments. In other words, when the environment of marine sport tourism does not bring the participants any discomfort or disturbance, they will have a positive attitude toward the recreational environment, and consequently fit in with it.

\section{Flow}

Flow is also known as flow experience. Csikszentmihalyi and Csikszentmihalyi (1975) indicate that flow is a special experience, a commonly shared experience mode in which participants completely focus on the activity with their consciousness concentrated on a very narrow scope, where unrelated perception and thoughts are screened out. Accordingly, once a recreation participant is equipped with the necessary skills and ability, and feels comfortable about the environment (software and hardware), he/she can obtain positive mood in the participation process. For example, a sea swimming contestant selects an appropriate contest group according to personal ability. When the environment meets safety standards, the contestant perceives that he/she can fit in the environment, and is likely to acquire flow experience during the contest. Therefore, the better one fits in with the environment, the more probable one will attain the status of flow.

\section{Satisfaction}

Satisfaction is based on a customer's assessment of the difference between his/her expectation of service and the actual experience (Stare, Deeman \& Klun, 2010). Participants of recreation will feel satisfied when they perceive that the activity performance is close to their original expectation, and vice versa. Kuo (1994) points out that the landscape variation of scenic spots can influence the mood of tourists; and different spatial structures and the sequence in which environment features are presented can cause different recreational experiences. In other words, recreational environment can influence the experience of participants, and consequently affect their satisfaction regarding the recreation. Lai (2003) exhibits the same viewpoint: the variation in personal traits and environmental factors will result in different recreational demands and motivation, and accordingly shape different satisfaction levels. Therefore, the recreationist-environment fit will be better when the environment can satisfy the demands of recreationists. 


\section{Destination Loyalty}

Destination loyalty refers to tourists' willingness to revisit and recommend the place (Oppermann, 2000). It reflects tourists' loyalty to the destination. Backman and Crompton (1991) state that the notion of loyalty can be divided into two parts: behavior and attitude. Behavior refers to multiple participation: the number of times receiving certain service, using facilities, and participating in specific activities. Attitude refers to the emotional preference level of tourists; it focuses on the interaction between recreationists and environment from the behavioral perspective. Yu and Xiong (2010) indicate that behavioral loyalty is commonly evaluated by the number of visits to the destination. Most researchers agree in using revisiting intention and word-of-mouth recommendation as major indices. The recreationist-environment fit is high when tourists approve of the environment, and are willing to revisit or recommend it to their relatives and friends.

\section{RESERCH METHODOLGY}

\section{Research Framework}

According to the research purpose and related literature, this study has established a framework (Figure 1) of the antecedent-consequence integrating model for assessing the recreationist-environment fit of the marine sport tourists in the Guaninting waters of Penghu.

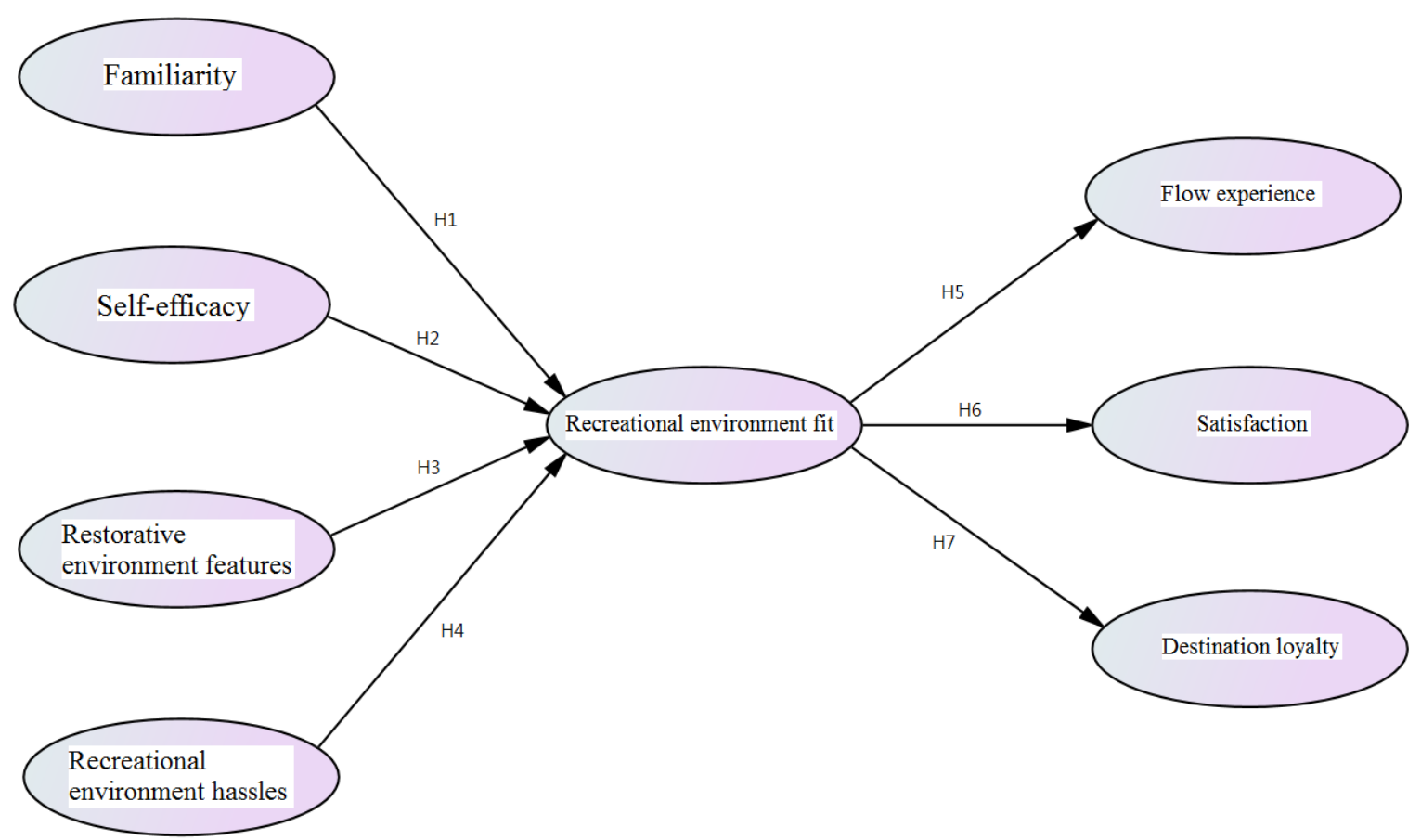

Figure 1. Framework of Research 


\section{Research Hypotheses}

Seven hypotheses are adopted according to the research purpose and related literature:

1. Familiarity has significant influence on R-E fit;

2. $\quad$ Self-efficacy has significant influence on R-E fit as well;

3. Restorative environment features have significant influence on R-E fit;

4. Recreational environment hassles have significant influence on R-E fit;

5. R-E fit has significant influence on flow experience;

6. R-E fit has significant influence on recreational satisfaction;

7. R-E fit has significant influence on destination loyalty.

\section{Subject Of Investigation}

Penghu archipelago waters are rich in marine resources. Participation in marine sports and recreation are the major activities of their tourists. Guaninting resort and waters are the main scenic spots of Penghu tourism; therefore, this research selected Guaninting resort as the location where the questionnaires were handed out. Our research subjects were the participants of marine sport tourism in the Guaninting waters of Penghu in 2014. Questionnaire survey was adopted along with site investigation and convenience sampling, with a total of 300 questionnaires handed out. After screening out 47 invalid ones which were unfinished or contained obvious errors, there were 253 valid questionnaires, for a valid response rate of $84.3 \%$.

\section{Research Tool}

Based on the literature review, this research's questionnaire included R-E fit, personal antecedents, environmental antecedents, recreation outcome and personal basic information. The scale was formulated and adapted by mainly consulting the notion and measurement of R-E fit scale raised by Tsaue, Liang and Lin (2012) and the antecedent-consequence model of R-E fit proposed by Tsaur and Lin (2012). In the questionnaire, the questions are arranged as follows: 19 questions deal with the six factors of R-E fit; eight questions with personal antecedents, including three questions on familiarity and five questions related to self-efficacy; 12 questions deal with environmental antecedents, including four questions on restorative environment features and eight questions on environmental hassles; eight questions are on recreation outcome, including four questions related to flow experience and four on satisfaction; three questions deal with destination loyalty; and seven questions relate to basic personal information. This study adopted the Seven-Point Likert scale for each dimension. The score of each question, from "strongly disagree" to "strongly agree" is rated from one to seven, respectively.

\section{Data Analysis}

This research first used SPSS 20.0 to conduct descriptive analysis of demographic statistic variables. Then Smart PLS 2.0 was used to analyze the relations among those variables and to examine the rationality of the research model, which was divided into two parts: measuring model and structural model, verified respectively in two separate stages. 


\section{RESULTS AND DISCUSSION}

\section{Demographic Statistical Variables}

Table 2 shows 253 subjects; their detailed demographic statistic variables are listed as follows:

1. For the gender variable, the percentages of males to females are $66.49 \%$ and $33.51 \%$, respectively; the number of males is slightly higher than that of females.

2. For the age variable, the largest age group is 21 -to-30 years old, accounting for $33.7 \%$, and followed by the 31 -to-40-year-old group, accounting for $24.9 \%$; the group under 20 covers $17.8 \%$, while the above-61years-old group is the smallest one, accounting for only $3.9 \%$.

3. For the marital status variable, the percentages of the married and unmarried are $38.7 \%$ and $61.3 \%$, respectively; the number of those unmarried is higher.

4. For the educational level variable, subjects with a bachelor degree have the biggest share, 57.3\%; the associate degree group is $17.8 \%$; the master's-degree-and-above group is $11.9 \%$; the percentages of those having high school diploma and those graduating from junior high school and under are $9.1 \%$ and $3.9 \%$, respectively.

5. For occupation variable, students form the biggest group, accounting for $29.2 \% ; 7.8 \%$ of the subjects are government employees; $13.8 \%$ are from industry-commerce service sector; besides, the percentages of other sectors, such as financial service, commerce, information electronic industry, agriculture-forestryfishery-husbandry, manufacturing, housekeeping (including retirees), and others are: 7.9\%, 7.9\%, 3.9\%, $3.9 \% ; 3.2 \%, 3.2 \%$ and $3.2 \%$, respectively.

6. For monthly income variable, $26 \%$ belong to the NT 20,001-40,000 bracket which is the biggest group; $22.8 \%$ belong to the NT 40,001-60,000 bracket; $17.7 \%$ belong to those with no income at all; $13.7 \%$ belong to the NT $60,001-80,000$ bracket; $11.8 \%$ belong to the NT 20,000-and-under bracket; $6.0 \%$ belong to the NT 80,001-100,000 bracket; the NT 100,001-and-above bracket contains the least number of subjects, accounting for only $2.0 \%$.

7. For principal residence variable, most of them, 37.2\%, come from Northern Taiwan; the subjects of the second largest group, 29.6\%, come from Southern Taiwan; the percentages of the Central-Taiwan group and off-shore-island group are $24.1 \%$ and $7.5 \%$, respectively; $1.6 \%$ of the subjects belong to the smallest group, which comes from Eastern Taiwan. 
Table 2. Statistics on Basic Information

\begin{tabular}{|c|c|c|c|}
\hline & Variable & Quantity & Percentage $(\%)$ \\
\hline \multirow{2}{*}{ Gender } & Male & 168 & 66.49 \\
\hline & Female & 85 & 33.51 \\
\hline \multirow{6}{*}{ Age } & Under 20 & 45 & 17.8 \\
\hline & 21-30-year-old & 85 & 33.7 \\
\hline & 31-40-year-old & 63 & 24.9 \\
\hline & 41-50-year-old & 30 & 11.8 \\
\hline & 51-60-year-old & 20 & 7.9 \\
\hline & Above 61 & 10 & 3.9 \\
\hline \multirow{2}{*}{ Marital status } & Married & 98 & 38.7 \\
\hline & Unmarried & 155 & 61.3 \\
\hline \multirow{5}{*}{ Educational level } & Junior high school and under & 10 & 3.9 \\
\hline & General and vocational high school & 23 & 9.1 \\
\hline & Junior college & 45 & 17.8 \\
\hline & College & 145 & 57.3 \\
\hline & Graduate school and above & 30 & 11.9 \\
\hline \multirow{13}{*}{ Occupation } & Government employee & 45 & 17.8 \\
\hline & Financial service & 20 & 7.9 \\
\hline & Industry-commerce service & 35 & 13.8 \\
\hline & Manufacturing & 8 & 3.2 \\
\hline & Commerce & 20 & 7.9 \\
\hline & Housekeeping (including retirees) & 8 & 3.2 \\
\hline & Medical personnel & 0 & 0 \\
\hline & Information-electronics industry & 10 & 3.9 \\
\hline & Students & 74 & 29.2 \\
\hline & Freelance & 15 & 6.0 \\
\hline & Transportation industry & 0 & 0 \\
\hline & Agriculture-forestry-fishery-husbandry & 10 & 3.9 \\
\hline & Others & 8 & 3.2 \\
\hline \multirow{7}{*}{ Monthly personal income } & Under NT 20,000 & 30 & 11.8 \\
\hline & NT $20,001-40,000$ & 65 & 26.0 \\
\hline & NT $40,001-60,000$ & 58 & 22.8 \\
\hline & NT $60,001-80,000$ & 35 & 13.7 \\
\hline & NT $80,000-10,000$ & 15 & 6.0 \\
\hline & NT 100,001 and above & 5 & 2.0 \\
\hline & No income & 45 & 17.7 \\
\hline \multirow{5}{*}{ Principal residence } & Northern Taiwan & 94 & 37.2 \\
\hline & Central Taiwan & 61 & 24.1 \\
\hline & Southern Taiwan & 75 & 29.6 \\
\hline & Eastern Taiwan & 4 & 1.6 \\
\hline & Off-shore islands & 19 & 7.5 \\
\hline
\end{tabular}

\section{Analysis Of Measuring Model}

\section{Convergent Validity}

Convergent validity is the level of how well the multi-variate-measured results belong to an identical latent construct. Table 3 shows that for every variable, its AVE is bigger than 0.5; the CR value is higher than 0.6 and factor loading is bigger than 0.7. Therefore, the model of this research exhibits convergent validity (Fornell and Larcker, 1981). 
Table 3. Reliability and Validity

\begin{tabular}{|c|c|c|c|c|}
\hline Dimension & Variable & Factor Loading & AVE & $\begin{array}{l}\text { Composite } \\
\text { Reliability }\end{array}$ \\
\hline \multirow{3}{*}{ Familiarity } & B1 & 0.882 & \multirow{3}{*}{0.794} & \multirow{3}{*}{0.920} \\
\hline & B2 & 0.899 & & \\
\hline & B3 & 0.892 & & \\
\hline \multirow{5}{*}{ Self-efficacy } & B4 & 0.813 & \multirow{5}{*}{0.776} & \multirow{5}{*}{0.945} \\
\hline & B5 & 0.841 & & \\
\hline & B6 & 0.927 & & \\
\hline & B7 & 0.923 & & \\
\hline & $\mathrm{B} 8$ & 0.897 & & \\
\hline \multirow{4}{*}{$\begin{array}{l}\text { Restorative } \\
\text { environment } \\
\text { features }\end{array}$} & $\mathrm{C} 1$ & 0.844 & \multirow{4}{*}{0.723} & \multirow{4}{*}{0.912} \\
\hline & $\mathrm{C} 2$ & 0.890 & & \\
\hline & $\mathrm{C} 3$ & 0854 & & \\
\hline & $\mathrm{C} 4$ & 0.812 & & \\
\hline \multirow{8}{*}{$\begin{array}{l}\text { Recreational } \\
\text { Environment } \\
\text { hassles }\end{array}$} & $\mathrm{C} 5$ & 0.849 & \multirow{8}{*}{0.520} & \multirow{8}{*}{0.895} \\
\hline & C6 & 0.816 & & \\
\hline & $\mathrm{C} 7$ & 0.760 & & \\
\hline & $\mathrm{C} 8$ & 0.647 & & \\
\hline & C9 & 0.636 & & \\
\hline & $\mathrm{C} 10$ & 0.654 & & \\
\hline & $\mathrm{C} 11$ & 0.681 & & \\
\hline & $\mathrm{C} 12$ & 0.691 & & \\
\hline \multirow{6}{*}{ R-E fit } & Environment resources & 0.784 & \multirow{6}{*}{0.526} & \multirow{6}{*}{0.869} \\
\hline & Social opportunity & 0.796 & & \\
\hline & Environment function & 0.724 & & \\
\hline & Environment facilities & 0.651 & & \\
\hline & Activity knowledge/skill & 0.697 & & \\
\hline & Operation/management & 0.693 & & \\
\hline \multirow{3}{*}{ Flow experience } & $\mathrm{D} 1$ & 0.903 & \multirow{3}{*}{0.836} & \multirow{3}{*}{0.938} \\
\hline & D2 & 0.936 & & \\
\hline & D3 & 0.904 & & \\
\hline \multirow{3}{*}{ Satisfaction } & D4 & 0.937 & \multirow{3}{*}{0.862} & \multirow{3}{*}{0.949} \\
\hline & D5 & 0.925 & & \\
\hline & D6 & 0.924 & & \\
\hline \multirow{3}{*}{ Destination loyalty } & D7 & 0.910 & \multirow{3}{*}{0.844} & \multirow{3}{*}{0.942} \\
\hline & D8 & 0.948 & & \\
\hline & D9 & 0.898 & & \\
\hline
\end{tabular}

\section{Discriminant Validity}

Discriminant validity is mainly used to examine the discrimination between two constructs. The correlation coefficient matrix in Table 4 indicates that the square root of each AVE value is obviously bigger than the absolute value of the correlation coefficient between any two corresponding constructs, which means the scale of this research has discriminant validity. 
Table 4. Correlation Coefficient Matrix of Dimensions

\begin{tabular}{|c|c|c|c|c|c|c|c|c|}
\hline & $\begin{array}{c}\text { Flow } \\
\text { Experience }\end{array}$ & $\begin{array}{c}\text { Restorative } \\
\text { Environment } \\
\text { Features }\end{array}$ & Familiarity & $\begin{array}{l}\text { Destination } \\
\text { Loyalty }\end{array}$ & Self-Efficacy & Satisfaction & $\begin{array}{c}\text { Recreational } \\
\text { Environment } \\
\text { Hassles }\end{array}$ & R-E Fit \\
\hline $\begin{array}{c}\text { Flow } \\
\text { experience }\end{array}$ & 0.914 & & & & & & & \\
\hline $\begin{array}{c}\text { Restorative } \\
\text { environment } \\
\text { features }\end{array}$ & 0.774 & 0.850 & & & & & & \\
\hline Familiarity & 0.527 & 0.462 & 0.891 & & & & & \\
\hline $\begin{array}{c}\begin{array}{c}\text { Destination } \\
\text { loyalty }\end{array} \\
\end{array}$ & 0.727 & 0.651 & 0.486 & 0.918 & & & & \\
\hline Self-efficacy & 0.610 & 0.611 & 0.587 & 0.504 & 0.880 & & & \\
\hline Satisfaction & 0.849 & 0.723 & 0.509 & 0.781 & 0.565 & 0.928 & & \\
\hline $\begin{array}{c}\text { Recreational } \\
\text { Environ- } \\
\text { mental hassles }\end{array}$ & 0.255 & 0.127 & 0.175 & 0.185 & 0.257 & 0.170 & 0.721 & \\
\hline R-E fit & 0.566 & 0.553 & 0.612 & 0.559 & 0.586 & 0.566 & 0.152 & 0.725 \\
\hline
\end{tabular}

\section{Structural Model Analysis}

In this study, a PLS structural model is used to examine the hypotheses. The results of the examination are shown in Figure 2: for familiarity $\rightarrow$ R-E fit, the path coefficient is 0.370 at $p<0.001$; for self-efficacy $\rightarrow$ R-E fit, the path coefficient is 0.215 at $\mathrm{p}<0.01$; for restorative environment features $\rightarrow \mathrm{R}-\mathrm{E}$ fit, the path coefficient is 0.251 at $\mathrm{p}<0.01$; for R-E fit $\rightarrow$ flow experience, the path coefficient is 0.567 at $\mathrm{p}<0.001$; for R-E fit $\rightarrow$ satisfaction, the path coefficient is 0.566 at $\mathrm{p}<0.001$; for $\mathrm{R}-\mathrm{E}$ fit $\rightarrow$ destination loyalty, the path coefficient is 0.560 at $\mathrm{p}<0.001$. The above figures represent a positive influence; therefore, as shown in Table 5, H1, H2, H3, H5, H6 and $\mathrm{H} 7$ are supported. However, in terms of the recreational environmental hassles $\rightarrow$ R-E fit, the path coefficient is "- 0.001 ", under the significant level, so H4 is unsupported. 


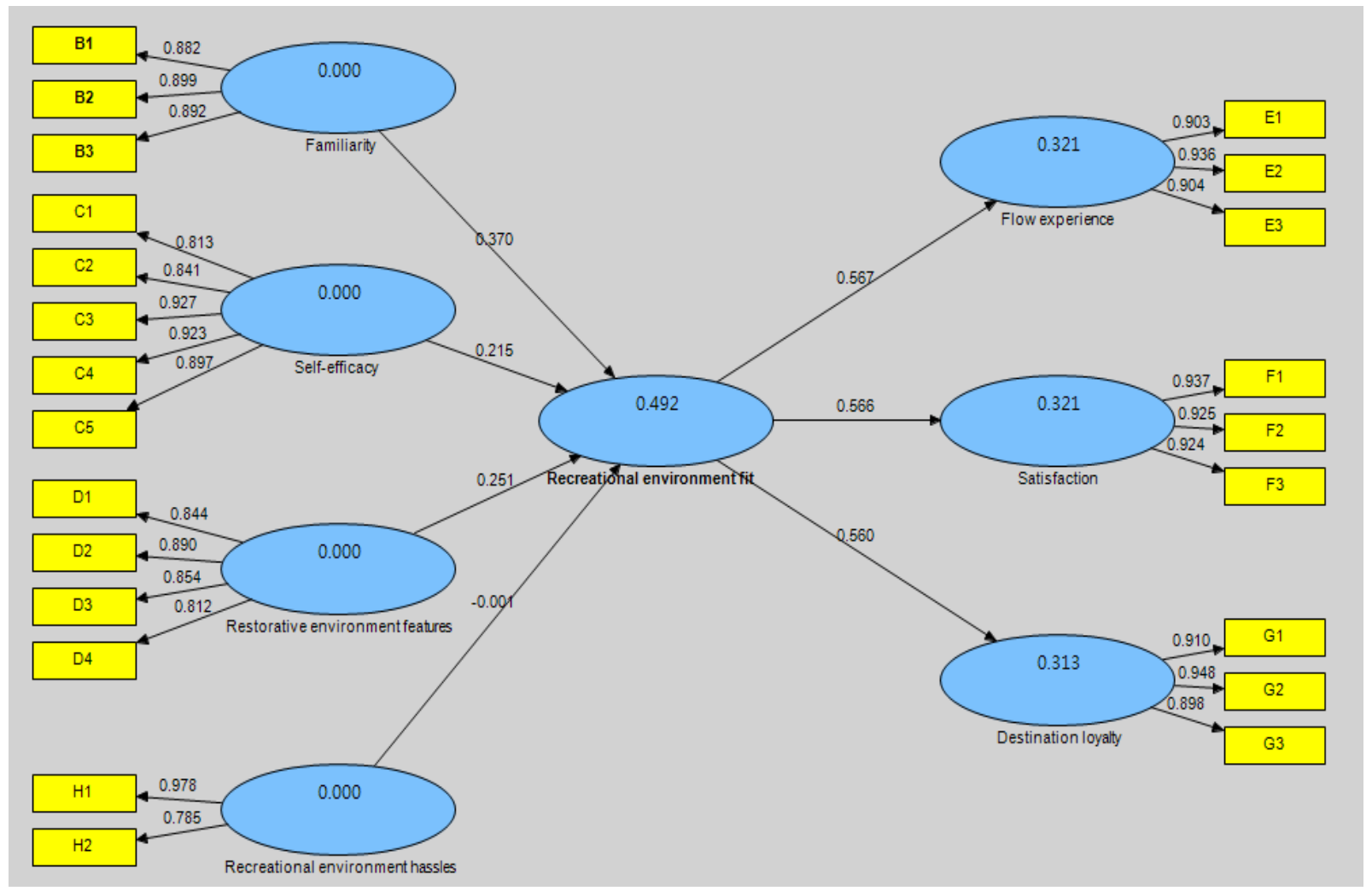

Figure 2. Results of Examination of Hypotheses

According to the analysis of path coefficients in Table 5, familiarity has significant impact on R-E fit. Therefore, Hypothesis 1 is supported. The research of Chen (2008) on the tourists of Kenting indicates that familiarity and visiting willingness are positively correlated. Hence, when the marine sport tourists of Penghu are more familiar with the water area and the activities in which they are going to participate, their cognition about the location and necessary equipment will be more clear and accurate, and consequently help them to obtain the experience they pursue, and to better fit in with the environment.

The research results reveal that self-efficacy has significant influence on R-E fit; therefore, Hypothesis 2 is supported. This result is consistent with that of Tsaur and Lin (2012), i.e. in regard to self-efficacy expectation, the marine sport tourists in Penghu show that they can evaluate their own ability and confidence, and handle the marine sport they choose. When the participants can manage to fit in with the environment on the basis of their competence, they can not only have better R-E fit, but can also increase the outcome expectation.

According to the path coefficient analysis results listed in Table 5, restorative environment features have significant influence on R-E fit, so Hypothesis 3 is valid. This result is the same as that of Tseng (2004), who investigated the influence of recreational activities on the health and recovery of people. Her research indicates that the healing effect and benefits of water bodies result from the glamour itself. Therefore, besides the plentiful sport facilities, both the maritime humanity and landscape of Penghu can help the marine sport tourists satisfy their demands during the participation process after arriving at the Guaninting waters, and consequently fit in better with the environment.

Based on the path coefficient analysis results listed in Table 5, the influence of recreational environment hassles on R-E fit is not significant; therefore, Hypothesis 4 is false, which echoes the conclusion of Tsaur and Lin (2012). The possible cause might be that different kinds of participants share the same part of water; therefore, the behavior of some tourists, like water skiers, inevitably hassle others, such as the swimmers. Besides, the 
overcrowded environment resulting from the popularity of the waters will also bother the participants, reducing their favoring the place, and consequently diminishing the R-E fit.

The research results show that R-E fit has significant influence on flow experience, so Hypothesis 5 is valid. This result is consistent with the viewpoint of Csikszentmihalyi and Csikszentmihalyi (1975), who believe that when participants feel that the surroundings are under control, they can reach the status of having their own way. Therefore, once the marine sport tourists possess appropriate ability and experience to embark on their activities, they can fit in with the site very well, bringing their skill into full play, and even feeling like they are carried away. This is the so-called "flow", which can only be experienced under perfect environment fit.

According to the path coefficient analysis of Table 5, R-E fit has significant influence on satisfaction, so Hypothesis 6 is supported. Chang (2006) points out that the motivation of sport tourism participants significantly influences their satisfaction. From this angle, the participants' perception about the recreational environment is one of their external motivations, which means the more the environment meets the demands of participants, the more satisfied the participants feel. Therefore, a better R-E fit can prompt the participants to perceive that the marine sport tourism can meet their expectation, and is worth the time and money.

This research reveals that R-E fit has significant influence on destination loyalty, so Hypothesis 7 is supported. This is consistent with the research results of Kozak (2001), who indicate that the more positive impression about the destination the tourists have, the higher their loyalty to the place will be. In terms of the marine sport tourism in Penghu waters, if the tourists want to revisit the place and recommend it to their friends and relatives, it implies that they approve of its environment and facilities, which means their R-E fit in Penghu is high.

Table 5. Examination Results of Hypotheses

\begin{tabular}{|c|c|c|c|}
\hline Hypothesis & Path Coefficient & T-Value & Examination Result \\
\hline $\begin{array}{l}\text { H1 } \\
\text { Familiarity } \rightarrow \text { R-E fit }\end{array}$ & 0.370 & $6.306 * * *$ & True \\
\hline $\begin{array}{l}\mathrm{H} 2 \\
\text { Self-efficacy } \rightarrow \text { R-E fit }\end{array}$ & 0.215 & $3.003 * *$ & True \\
\hline $\begin{array}{l}\mathrm{H} 3 \\
\text { Restorative environment features } \rightarrow \mathrm{R}-\mathrm{E} \text { fit }\end{array}$ & 0.251 & $3.107 * *$ & True \\
\hline $\begin{array}{l}\text { H4 } \\
\text { Recreational environment hassles } \rightarrow \text { R-E fit }\end{array}$ & -0.001 & 0.025 & False \\
\hline $\begin{array}{l}\text { H5 } \\
\text { R-E fit } \rightarrow \text { Flow experience }\end{array}$ & 0.567 & $9.840 * * *$ & True \\
\hline $\begin{array}{l}\text { H6 } \\
\text { R-E fit } \rightarrow \text { Satisfaction }\end{array}$ & 0.566 & $10.180 * * *$ & True \\
\hline $\begin{array}{l}\text { H7 } \\
\text { R-E fit } \rightarrow \text { Destination Loyalty }\end{array}$ & 0.560 & $9.617 * * *$ & True \\
\hline
\end{tabular}

\section{CONCLUSIONS AND SUGGESTIONS}

\section{Conclusions}

In this research, through questionnaire survey and relation analysis among the variables, the following conclusions are obtained:

1. Familiarity has significant influence on R-E fit;

2. $\quad$ Self-efficacy has significant influence on R-E fit;

3. Restorative environment features have significant influence on R-E fit;

4. Recreational environment hassles have little significant influence on R-E fit;

5. R-E fit has significant influence on flow experience;

6. R-E fit has significant influence on recreational satisfaction;

7. R-E fit has significant influence on destination loyalty. 


\section{Suggestions}

According to the empirical data analysis and the above conclusions, several suggestions are drawn up for future researches and business management:

\section{For Marine Sport Tourists}

According to this research, familiarity has positive influence on R-E fit. Therefore, for the people who participate in marine sports, a basic understanding about the oceanic environment should be acquired before heading to the destination. Take Guaninting waters as an example; people can obtain its traffic information and know where its leisure seawall is located via the Internet or telephone. In addition, some smartphone APPs also provide another channel for acquiring tourism information of Magong City. The Tourism Department of Penghu County Government has posted information of scenic spots of Magong, Baisha, Huxi, Xiyu, Qimei and Wang'an on their official website, and even downloading of electronic maps is also available. Recreationists should collect relevant information in order to know where to eat, drink and have fun after they arrive.

Xiying Rainbow Bridge, for example, is the place for watching fireworks during the Penghu Fireworks Festival, and the coast near Haitunting is one of the best places to watch it. In other words, through the collection of tourism information, people can enjoy colorful, diversified sport tourism, which can consequently make them love and revisit the destination, generating familiarity toward it.

Furthermore, this research has proven the positive influence of self-efficacy on R-E fit; hence, it is suggested that marine sport tourists should evaluate if they possess the ability required for each activity. Since all of those operational skills demand professional instruction, the participants should start from the experience curriculum offered by associated organizations, honing their skill step by step. Otherwise, they can attend the courses organized by the Penghu Sailing Association. Through these measures, the participants can gradually perceive that they have become part of the marine sport tourism, forming a better R-E fit.

Besides, this research reveals that R-E fit also has significant influence on the flow experience of participants. Therefore, it is suggested that the windsurfers should devote more time to the sport after gaining better comprehension of the environment, in order to achieve a balance between their personal skill and the challenge of the sport. Consequently, under these appropriate circumstances, windsurfers can ensure a sense of control and positive mood, eventually generating flow experience.

\section{For The Administration Of Marine Sport Tourism}

This research has proven the influence of restorative environment features on R-E fit. Therefore, it is suggested that the associated administrations should increase the "compatibility" of marine sport tourism through impeccable software and hardware, thus allowing different kinds of participants to obtain satisfaction from their activities. In order to achieve this goal, the authorities should offer education programs. The fire department, coast guard, Jet Ski businesses, and local maritime rescue group, for example, can jointly organize Jet Ski riding and maritime rescue camps. These programs can prompt the maintenance of marine environment, safety precaution of Jet Ski riding, maritime rescue ability and consequently reduce related accidents. By organizing the programs, for the hardware part, the authorities and Jet Ski businesses can work together to establish safe environments for the Jet Ski sport; for the software part, they can improve the public awareness of drowning prevention, allowing the participants to enjoy water activities without worry.

Moreover, since R-E fit can influence satisfaction, it is suggested that, besides improving the software and hardware, the authorities should do more to reduce the gap between the expectation of marine sport tourists and their actual experience. The prosperity of Penghu marine sport tourism, for example, not only prompts the growth of travel agencies, but also causes the declination of traditional fishing villages. Therefore, the addition of fishing village resources, like night squid fishing, and trawling to the daytime sport activities, will diversify marine sport tourism, offering the tourists more opportunities to know the people and culture of Penghu, increasing their satisfaction, while conserving the traditional culture of fishing villages. 
Besides, diverse options to the itinerary are available because of the government-held annual festivities, such as Penghu Music Festival, Penghu Seafood Festival, Fireworks Festival, Jibei Tidal-Stone-Weir Cultural Festival and Penghu Sailboard \& Cobia Tourism Festival. They not only help to publicize Penghu, but also, thanks to the combination of marine resources and marine sports, leave a good impression with the tourists, increasing their satisfaction.

Finally, since R-E fit has a positive influence on destination loyalty, the administrations should enhance the attraction of Penghu by putting more effort into merging unique local features into marine sport tourism, and combining delicacy and guesthouse experience in the itinerary. These measures can offer novel experiences to the tourists every year. In addition, the unique weather of Penghu entails a big difference of tourism between slow and boom seasons; hence, the administration should come up with special programs to solicit tourists during the slow season.

Besides using the windsurfing racing to market the tourism itinerary, an alternative proposal by Yan (2009), a light rail sail car, for example, can be an option for the wintertime in Penghu. It is a combination of rail and sailboat, which is supported by an elevated rail. Seats are arranged on the flanks inside the car, which clutches the rail with its wheels, so it will not incline and waver in strong winds. The vehicle is then propelled by the wind and is maneuvered by the driver by controlling the angle of the sail. Like the MRT, it can circle around the city, becoming its unique transportation.

Since there are few tall buildings in Penghu, the elevated sail car, whose height will be slightly higher than that of houses around, can easily ride the wind and present a great panoramic view of Penghu for its passengers. Wind, which has been the natural enemy of Penghu tourism, will create an opportunity for the Island due to the sail car. This idea, using natural resources to develop unique recreational facility, can not only turn a problem into an opportunity, but also give the tourists a positive impression of the whole tourism environment of Penghu, increasing their destination loyalty.

\section{For Future Research}

This research selected the marine sport tourists of Guaninting in Penghu as subjects to investigate the influence of R-E fit on dimensions such as personal antecedents, environmental antecedents and recreation outcome. In terms of practical contributions, this study helps people to understand how to enrich their precious journey to the popular spots of marine sport tourism in Penghu. It especially indicates, through the improvement of personal antecedents, that tourists can better fit in with the marine sport tourism environment, and consequently obtain a better experience. Besides, with the help of this study, relevant administrations can realize which factors are influencing the experience of marine sport tourists and which require improvement, like software, hardware and the arrangement of activities. In addition, with the analysis and suggestions provided by this study, the administrations can better understand how to narrow the difference of tourist arrivals between slow and boom seasons.

In terms of the academic contribution, the notion of "fit" has been primarily applied to organization management, and rarely applied to the recreation field. Therefore, this research not only has expanded the application of the notion of "fit", but has also proven the possibility of applying it to marine sport tourism. Through this empirical study, some conclusions are obtained to form a stepping stone for future researches adopting the notion of "fit" in the recreational field. Cross references can be made between this research and future studies, helping to prompt the development of this field.

Since the variables of this research are adapted from other previous studies and then applied to the theme of marine sport tourism, among the dimensions discussed above, there might be some undiscovered variables awaiting further investigation. The personal antecedents, for example, might still have other influential variables besides the familiarity and self-efficacy probed in this paper. The behavior of recreationists (motivation, demand, obstacles, etc.), for instance, may influence R-E fit as well; therefore, its corresponding investigation in the future can offer us a more complete picture about the influencing factors of R-E fit. In addition, different recreational activities require different space. The recreational environment and natural resources required for land-based activity, for example, cannot be compared to those for marine sports. Hence, the scope of future researches should be more diverse in order to provide substantial benefits to recreationists and associated administrations. 


\section{Epilogue}

Taiwan Island has 36, 000-square-kilometers of land area surrounded by the sea, which boasts rich marine resources; however, marine sports have long been ignored by its people. In recent years, the government has progressively promoted marine education. The attitude of our nationals to the ocean has changed from fear to acceptance, since the issue of ocean white paper in 2001. This transformation can be verified by the crowded tourists attracted to the waters of every popular spot over recent years. Under this kind of spatio-temporal background, Taiwan's marine sport tourism has gradually developed, and more and more cities and counties are offering different options with the combination of marine sports and tourism activity.

Although marine sport tourism has brought positive values and benefits to the tourism industry, sustainable management is still an issue faced by associated administrations. On the other hand, marine sport tourists are also beginning to contemplate how to make their recreational experience better than just eating, drinking and having fun. Therefore, this paper started with the notion of "fit", selecting the Guaninting waters of Penghu as the research scope, and investigating the relation between marine sport recreationists and environment through an empirical research. Besides, in order to promote sustainable development of marine sport tourism, suggestions are proposed for the participants and administrations to have an integral understanding of their recreational environment while trying to boost their tourism industry.

\section{AUTHOR INFORMATION}

Dr. Cheng-Lung Wu; Associate Professor of Marine Recreation; Ed.D. in Leisure Studies, Oklahoma State University (2004); Head of the Department of Marine Sports \& Recreation (2004-2006; 2014-now), National Penghu University of Science \& Technology, Taiwan. R. O. C.; Member of the Taiwan Society for Sport Management; Dr. Wu's research interests include marine recreation, sports tourism, and leisure behavior. He can be reached at: jerrywu@gms.npu.edu.tw

\section{REFERENCES}

Backman, S. J., \& Crompton, J. L. (1991). Differentiating between high, spurious, latent, and low loyalty participants in two leisure activities. Journal of Park and Recreation Administration, 9(2), 1-17.

Bammel, G . \& Burrus-Bammel, L. L. (1982).Leisure and Human Bahavior. Dubuge, IA : Wm. C. Brown Company Publisher.

Bandura, A. (1977). Self-efficacy: Toward a unifying theory of behavior change. Psychological Review, 84(2), 191-215.

Booth, K. L., Cessford, G. R., McCool, S. F., \& Espiner, S. R. (2011). Exploring visitor experiences, crowding perceptions and coping strategies on the Milford, New Zealand. Journal Science for Conservation, 313, 6-91.

Bricker, K. S. \& Kerstetter, D. L. (2000). Level of specialization and place attachment: an exploratory study of whitewater recreationists, Leisure Science, 22, 233-257.

Cable, D. M., \& DeRue, D. S., 2002. The convergent and discriminant validity of subjective fit perceptions. Journal of Applied Psychology, 87(5), 875-884.

Chang, C. (2006). A study of sports tourism satisfaction of the 2004 Penghu Marathon Race of the Chinese Worldwide, TPEC Press, 14, 252-270.

Chang, H., Lin, J., Chen, C. \& Chan, C. (2010). A study of residents recognized on costal sport tourism developing impact in Penghu, Leisure Study, 1(4) , 19-43.

Chen, Y. (2008). A study of the relationship between the familiarity with the tourist destinations and the willingness of visit (Unpublished master's thesis). National Kaohsiung University of Hospitality and Tourism, Kaohsiung, Taiwan.

Cheng, H., Lin, S. \& Tsai, J. (2011). A Study of residents' marine recreation sport participation, recognized on ceveloping impact, and attitude for future development in Penghu, Journal of Leisure and Recreation Industry Management, 4(3), 25-44.

Csikszentmihalyi, M., \& Csikszentmihalyi, I. (1975). Beyond boredom and anxiety. San Francisco: Jossey- Bass.

Edward, J. R., (1991). Person-job fit: A conceptual integration, literature review, and methodological critique. In Cooper C. L. \& Robertson, I. T. (Eds). International review of industrial and organizational psychology (pp. 283-357). Oxford, England: John Wiley \& Sons.

Fornell, C. and Larcker, D. F. (1981). Structural equation models with unobservable variables and measurement error: 
algebra and statistic. Journal of Marketing Research, 18, 382-388.

Folkman, S., \& Lazarus, R. S. (1984). Sress, appraisal, and coping. New York: Springer Publishing Company.

Folkman, S., Lazarus, R. S., Christine Dunkel-Schetter, DeLongis, A., \& Gruen, R. J. (1986). Dynamics of a stressful encounter: Cognitive appraisal, coping, and encounter outcomes. Journal of Personality and Social Psychology, 50(5), 992-1003.

Huan, T., Shen, C. Weng, T. \& Tai, D. (2002). Snowy Pearl-Tibet: The study of religious tourists' travel motivation and satisfaction, Travel Management Research, 1(2): 23-42

Hsu, W. (2005). Marine tourism and recreation development in Taiwan: Current status and Opportunities, Yan Kao Shuang Yue Kan, 29(4) , 56-64

Jacob, G. R., and Schreyer, R. (1980). Conflict in outdoor recreation: A theoretical perspective. Journal of Leisure Research, 12(4), 368-380.

Kozak, M. (2001). Repeaters' behavior at two distinct destinations. Annals of Tourism Research, 28(3), $784-807$.

Kristof-Brown, A. L., Zimmerman, R. D., \& Johnson, E. C. (2005). Consequences of individuals' fit at work: A metaanalysis of person-job, person-organization, person-group, and person-supervisor fit. Personnel Psychology, 58(2), 281-342.

Kuo, J. (1994). A dynamic approach to evaluate the nature of recreation experience in relation to environmental attributes, Journal of Outdoor Recreation Study, 7(2), 37-56.

Lai, F. (2003). A study of visitors' image factor for recreational satisfaction -The use of hierarchical linear model (Unpublished master's thesis). Chaoyang University of Technology, Taichung, Taiwan.

Lauver, K. J., \& Kristof-Brown, A. (2001).Distinguishing between employees' perceptions of person-job and personorganization fit. Journal of Vocational Behavior, 59(3), 454-470.

Oppermann, M. (2000) Tourism destination loyalty, Journal of Travel Research 39, 78-84.

Muchinsky, P. M., \& Monahan, C. J. (1987). What is per-son-environment congruence? Supplementary versus complementary models of fit. Journal of Vocational Behavior, 31(3), 268-277.

Onofri, L., \& Nunes, P. (2013). Beach 'lovers' and 'greens': A worldwide empirical analysis of coastal tourism. Ecological Economics, 88, 49-56.

Oppermann, M. (2000). Tourism destinations loyalty. Journal of Travel Research, 39 (11), 78-84

Prentice, R., \& Andersen, V. (2000) Evoking Ireland modeling tourist propensity. Annals of Tourism Research, 27 (2), 490-516.

Tseng, T. (2004). A study of Field and Non-field landscape experience and Health Heals. Travel management research, 4(2), 99-118.

Ramdas, M., \& Mohamed, B. (2014).Impacts of tourism on environmental attributes, environmental literacy and willingness to pay: A conceptual and theoretical review. Procedia - Social and Behavioral Sciences, 144, 378391.

Schuster, R. M., Hammitt, W. E., \& Moore, D. (2006). Stress appraisal and coping response to hassles experienced in outdoor recreation settings. Leisure Sciences. 28, 97-113.

Stare, J., Deeman, M., and Klun, M. (2010). Relationship between job satisfaction and customer satisfaction in public sector using a structural equation model. Journal of US-China Public Administration, 7(4), 37-64.

Tsaur, S. H., Liang, Y. W., \& Lin, W. R. (2012). Conceptualization and measurement of recreationist-environment fit. Journal of Leisure Research, 44(1), 108-128.

Tsaur, S., \& Lin, W. (2012). Antecedents and consequences of recreationist- environment fit: A study of Mt. Yushan climbers, Journal of Outdoor Recreation Study, 25(4), 79-98.

Tseng, T. (2004). A study of field and non-field Landscape experience and Health Heals, Travel Management Research, 4(2), 99-118

Valentine, S., Godkin, L., \& Lucero, M. (2002). Ethical context, organizational commitment, and person-organization fit. Journal of Business Ethics, 41(4), 349-360.

Vogel, R. M., \& Feldman, D. C. (2009). Integrating the levels of person-environment fit: The roles of vocational and group fit. Journal of Vocational Behavior, 75(1), 68-81.

Williams, D. R., Patterson M. E., Roggenbuck, J. W., \& Watson, A. E. (1992) Beyond the commodity metaphor: Examining emotional and symbolic attachment to place. Leisure Sciences, 14, 29-46.

Yen, C. (2015, January 21st). Rescuing Penghu with the light railway and recreational windsurfing cars. Retrieved from :http://udn.com/NEWS/OPINION/X1/5155852.shtml

Yu, Y., \& Xiong, J. (2010). A Recent Progress on Western Tourism Destination Loyalty Research, World Regional Studies, 19(2), 69-7. 